\title{
Bench-to-bedside review: the effects of hyperoxia during critical illness
}

\author{
Hendrik J. F. Helmerhorst ${ }^{1,2^{*}}$, Marcus J. Schultz ${ }^{2,3}$, Peter H. J. van der Voort ${ }^{4,5}$, Evert de Jonge ${ }^{1}$ \\ and David J. van Westerloo ${ }^{1}$
}

\begin{abstract}
Oxygen administration is uniformly used in emergency and intensive care medicine and has life-saving potential in critical conditions. However, excessive oxygenation also has deleterious properties in various pathophysiological processes and consequently both clinical and translational studies investigating hyperoxia during critical illness have gained increasing interest. Reactive oxygen species are notorious by-products of hyperoxia and play a pivotal role in cell signaling pathways. The effects are diverse, but when the homeostatic balance is disturbed, reactive oxygen species typically conserve a vicious cycle of tissue injury, characterized by cell damage, cell death, and inflammation. The most prominent symptoms in the abundantly exposed lungs include tracheobronchitis, pulmonary edema, and respiratory failure. In addition, absorptive atelectasis results as a physiological phenomenon with increasing levels of inspiratory oxygen. Hyperoxia-induced vasoconstriction can be beneficial during vasodilatory shock, but hemodynamic changes may also impose risk when organ perfusion is impaired. In this context, oxygen may be recognized as a multifaceted agent, a modifiable risk factor, and a feasible target for intervention. Although most clinical outcomes are still under extensive investigation, careful titration of oxygen supply is warranted in order to secure adequate tissue oxygenation while preventing hyperoxic harm.
\end{abstract}

\footnotetext{
* Correspondence: h.j.f.helmerhorst@lumc.nl

'Department of Intensive Care Medicine, Leiden University Medical Center, Albinusdreef 2, Leiden 2300 RC, The Netherlands

${ }^{2}$ Laboratory of Experimental Intensive Care and Anesthesiology, Academic Medical Center, Meibergdreef 9, Amsterdam 1105 AZ, The Netherlands Full list of author information is available at the end of the article
}

\section{Introduction}

Oxygen is a vital element in human survival and plays a major role in a diverse range of biological and physiological processes. In medical practice, it is among the most universally used agents for the treatment of critical illness [1] and part of the routine treatment in acute shock and emergency medicine [2]. To ensure sufficient oxygenation, oxygen therapy during mechanical ventilation, anesthesia, and resuscitation usually exceeds physiological levels. However, Renaissance physician Paracelsus noted: "nothing is without poison-the poison is in the dose". This accounts for many aspects in medicine but may also be applicable to the oxygen molecule [3]. The concept of oxygen toxicity was described in the late 19th century following the pioneering efforts of James Lorrain Smith and Paul Bert, but it was not until a century later that the effects of hyperoxia were increasingly studied. Although several lines of evidence indicate that hyperoxia may be harmful, robust interventional studies are still limited. To develop adequate recommendations for optimal oxygen levels, it is important to extend our current understandings of hyperoxia-induced injury. The aim of this review is to provide a comprehensive overview of the effects of hyperoxia from the bench and the bedside. The first part will focus on established insights and recent experimental and translational advances; the latter part addresses pathophysiological concepts, clinical studies, and implications for therapy.

\section{Pathogenesis from the benchside Reactive oxygen species}

Reactive oxygen species (ROS) are versatile molecules that can be essential in the regulation of intracellular signaling pathways and in host defense [4]. However, ROS have also repeatedly been postulated to be of major significance in tissue damage, organ dysfunction, and clinical disease. In regard to oxygen toxicity, it is frequently assumed that it is not oxygen itself that exerts toxic effects but merely the ROS that are generated as an undesirable 
by-product of adenosine triphosphate synthesis during aerobic cellular metabolism. The implications for the lungs are probably the most prominent as lung tissue is continuously and abundantly exposed to oxygen and its by-products. In physiological circumstances, ROS are formed in the electron transport chain during proton transport across the inner mitochondrial membrane. Mitochondrial oxidative phosphorylation is the most important source of oxygen species, but ROS may also be generated in response to exogenous stimuli, such as microbes, cytokines, and xenobiotics [5]. Antioxidant tasks are accomplished by enzymes as catalases, glutathione peroxidases, thioredoxins, and peroxyredoxins. These enzymes use electron donors in order to avoid the intermediate formation of the hydroxyl radical $(\mathrm{OH} \cdot)$, which is a strongly reactive oxidant. In this process, superoxide dismutase is an important antioxidant enzyme as it efficiently reduces the concentration of the superoxide anion $\left(\mathrm{O}_{2} \cdot{ }^{-}\right)$ by facilitating its rapid conversion in hydrogen peroxide $\left(\mathrm{H}_{2} \mathrm{O}_{2}\right)$ or oxygen $\left(\mathrm{O}_{2}\right)$. In general, ROS generation from mitochondria increases with oxygen tension and is dependent on the clinical balance between the underlying condition and oxygen supply [6]. In response to bacterial invasion, neutrophils can also produce large amounts of ROS that may initially be beneficial in the host defense against several pathogens. Fortunately, the lungs are principally well protected against oxygen toxicity by adequate intra-and extracellular antioxidant activity. Besides this physiological activity, additional antioxidants can be recruited in the epithelial lining fluid [7]. However, when the production of ROS exceeds the limits of counteraction by antioxidant responses, ROS concentrations reach inadequate levels and a cellular state of oxidative stress manifests. Oxidative stress refers to the imbalance caused by increased ROS formation or deficient oxidant suppressors [8]. When antioxidant systems are insufficient during critical illness and mechanical ventilation, supplemental oxygen can cause accumulation of oxygen radicals and may initiate or perpetuate oxygen toxicity. Moreover, ROS control can be markedly influenced by aging, genetic factors, and pharmacochemical agents [6].

\section{Cell death}

When the delicate homeostatic balance is disturbed, oxidative stress leads to damage of nucleic acids, proteins, and lipids, resulting in cell death by both apoptotic and necrotic pathways [9]. Necrosis is characterized by incomplete apoptosis and supported by integrity loss of the cell membrane and cytoplasmic swelling. Programmed cell death by apoptosis can be achieved through extrinsic or intrinsic pathways, concomitantly. The extrinsic pathway is triggered by extracellular signals that stimulate intracellular apoptotic cascades after binding the cell membrane. The intrinsic apoptotic pathway is initiated by increased mitochondrial ROS formation. Subsequently, the opening of transition pores is facilitated, making the outer mitochondrial membrane more permeable for proapoptotic components. These components can then pass to the cytoplasm and induce a state of intracellular stress. When this occurs in both endothelial and epithelial cells, lytic damage and cell death contribute to interstitial pulmonary edema and impaired gas exchange by means of alveolar collapse and disintegration of the alveolar-capillary barrier.

\section{Cell damage and inflammatory pathways}

In addition to direct cell death by necrosis or apoptosis, cellular disruption caused by hyperoxia and ROS has been shown to release endogenous damage-associated molecular pattern molecules (DAMPs) that alert the innate immune system [10-12]. DAMPs, or alarmins, are cell fragments released during cellular dysfunction and sterile injury and act as pleiotropic modulators of inflammation. During oxidative stress, mitochondrial damage is a pivotal cause of extracellular hazardous content including both free radicals and DAMPs. Because they resemble bacterial DNA, circulating mitochondrial DAMPs are efficiently recognized by pattern recognition receptors and activate polymorphonuclear neutrophils (PMNs). Subsequently, PMNs release interleukins and contribute to a sterile inflammatory reaction and, ultimately, neutrophilmediated organ injury. In response to hyperoxia-mediated ROS production, resident lung cells initiate the release of various cytokines. Chemotactic factors orchestrate the inflammatory response by attracting inflammatory cells to the pulmonary compartment. Recruited neutrophils and monocytes, in turn, are significant sources of additional ROS, conserving a vicious cycle leading to further tissue damage (Fig. 1). Under enduring conditions of injury to pulmonary epithelium and increasing alveolar permeability, cytokines can translocate from the alveolar space to the systemic circulation, creating a systemic inflammatory response, in which cytokines are efficiently activated and phagocytosis by alveolar macrophages is hampered [13]. Cytokine concentrations decrease after long-term exposure, suggesting that a fast upregulation of inflammatory action is followed by a gradual impairment of the innate immune system [14]. Besides mitochondrial damage, the inflammatory actions of oxygen are importantly modulated by hypoxia-inducible factor (HIF) $[15,16]$. HIF- $1 \alpha$ is thought to be upregulated during relative changes in oxygenation and accordingly responds to normoxia as a relative hypoxic state directly after hyperoxia. Through this mechanism, intermittent hyperoxia may trigger a paradoxical phenomenon in which the genetic expression of inflammatory mediators and erythropoietin is stimulated in the absence of true tissue hypoxia [17]. 


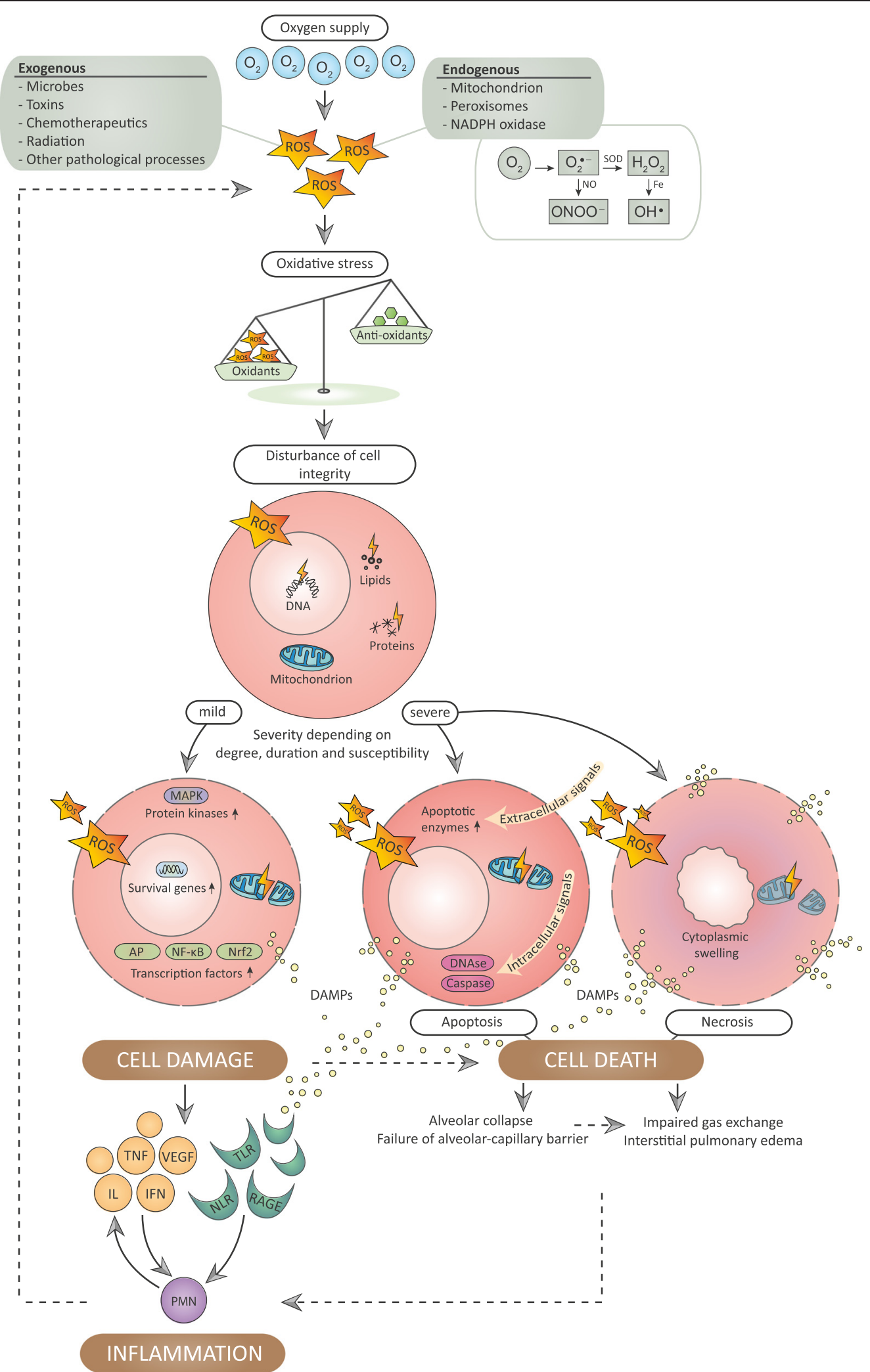

Fig. 1 (See legend on next page.) 
(See figure on previous page.)

Fig. 1 Vicious cycle of hyperoxia-induced cell injury. AP activator protein, DAMP damage-associated molecular pattern molecules, $\mathrm{H}_{2} \mathrm{O}_{2}$ hydrogen peroxide, IFN interferon gamma, IL interleukin, MAPK mitogen-activated protein kinase, NADPH nicotinamide adenine dinucleotide phosphate, NF-KB nuclear factor kappa B, NLR nod-like receptor, Nrf2 nuclear factor-2 erythroid related factor-2, $\mathrm{O}_{2}$ oxygen, $\mathrm{O}_{2}{ }^{-}$superoxide, $\mathrm{OH}$ hydroxyl radical, $O N O O^{-}$peroxynitrite, PMN polymorphonuclear neutrophil, RAGE receptor for advanced glycation end products, ROS reactive oxygen species, TLR Tolllike receptor, TNF tumor necrosis factor, VEGF vascular endothelial growth factor

\section{Animal studies}

Principal insights in hyperoxia-induced mechanisms have been obtained from experimental models. The first animal studies documented structural morphologic and biochemical changes in the lungs of a wide variety of animal species that were exposed to hyperoxia [18]. Pioneering studies using conscious dogs postulated that normobaric hyperoxia decreased metabolic rate and altered hemodynamics [19, 20]. These findings were reproduced in primates in which progressive pulmonary injury, interstitial edema, and inflammatory activation were observed [21]. In later experiments, biochemical effects of ROS and interventional targets on the molecular level were more intensively studied in spontaneously breathing animals in hyperoxic environments and showed both detrimental and protective potential [22-26]. Recent experiments were performed in mechanically ventilated rodents, rabbits, and pigs, mimicking the clinical environment of critically ill patients [27-31]. In this context, the interaction between injurious ventilation and concurrent hyperoxia was shown to transcend lung injury by alveolar distention alone [22, 32-35]. However, studies in mechanically ventilated animals are usually restricted to short exposure periods [32, 34-38], even though hyperoxia may induce time-dependent inflammation [23]. To improve our understanding of the impact of long-term exposure to both mechanical ventilation and hyperoxia, future studies involving mechanical ventilation of longer duration and with clinically relevant settings are essential for a robust representation of the ICU environment.

\section{Pathogenesis from the bedside}

\section{Hyperoxia-induced tissue injury}

Under normobaric circumstances, the side effects of oxygen are initially restricted to the lungs. However, when hyperoxia manifests for prolonged periods or under hyperbaric conditions, other organs are concurrently at risk as more oxygen is dissolved in plasma [6]. The amount of dissolved oxygen will readily increase at partial pressures of arterial oxygen $\left(\mathrm{PaO}_{2}\right)$ exceeding $100 \mathrm{~mm}$ $\mathrm{Hg}$. Oxyhemoglobin saturation is nearly complete when $\mathrm{PaO}_{2}$ approaches this level and the carrying capacity of hemoglobin is therefore quickly overcharged with increasing fractions of inspired oxygen $\left(\mathrm{FiO}_{2}\right)$.

The harmful effects depend on underlying conditions, duration, and degree of the hyperoxic exposure. Rigid thresholds where harm exceeds the perceived benefits are not exactly known and may vary between subgroups [39]. Most pathophysiological changes originate rapidly and are rather universal effects, but the effects of hyperoxia are assumed to be time-and dose-dependent [40]. In general, excessive oxygen supply causes absorptive atelectasis by displacement of alveolar nitrogen. The progressive washout of nitrogen coincides with the abundant presence of oxygen in the alveoli which, driven by a steep pressure gradient, rapidly diffuses into the mixed venous blood. As a result, the alveolar volume is markedly reduced and leads to increased ventilation/perfusion mismatch by (partial) alveolar collapse and impaired gas exchange, which can be attenuated by applying positive end-expiratory pressure [41]. Impaired mucociliary clearance by hyperoxia contributes to obstructive atelectasis, and altered surfactant metabolism facilitates adhesive atelectasis through alveolar instability and collapse. Several lines of evidence indicate further effects of breathing high oxygen levels in animals and healthy subjects $[1,42]$, but evidence of pulmonary toxicity in a clinical scenario is limited [43]. The pathological features of this condition are commonly referred to as the Lorrain Smith effect [44] and are characterized by tracheobronchitis, which can be accompanied by pleuritic pain, bronchial irritation, cough, and sore throat. Symptoms may spread from the upper airways into the lungs, where diffuse alveolar damage manifests and contributes to edema, vascular leakage, arteriolar thickening, pulmonary fibrosis, and emphysema, reflected by progressive paradoxical hypoxia, dyspnea, and tachypnea. Additionally, prolonged hyperoxic exposure alters the microbial flora in the upper airways and further increases the risk of secondary infections and lethality. Notably, these pulmonary effects are often in addition to the primary (e.g., pneumonia) and secondary (e.g., ventilator-induced lung injury) lung injury, which are accompanied by inflammatory responses.

The central nervous system is typically the first to suffer from the effects of excessive ROS formation. The spectrum of neurological symptoms is referred to as the Paul Bert effect and ranges from nausea, dizziness, and headache to vision disturbances (retinal damage), neuropathies, paralysis, and convulsions [1].

Vascular effects of hyperoxia have been well documented and may have both harmful and beneficial effects. Arterial hyperoxia increases the systemic vascular resistance and induces vasoconstriction, which may impair organ perfusion, especially in the cerebral and coronary 
region [45-47]. Accompanying cardiovascular alterations result from even short-term exposure and include a decrease in heart rate, stroke volume, and cardiac output [48]. However, hyperoxia is not a universal vasoconstrictor in all vascular regions, and blood flow may be redistributed to the hepatosplanchnic circulation in septic shock $[1,49]$. Alternatively, the administration of oxygen promotes hemodynamic stabilization during vasodilatory shock, decreases intracranial pressure by cerebral vasoconstriction, and preserves tissue oxygenation during hemodilution $[2,50]$.

\section{Clinical studies \\ Critical care}

Recent studies assessing the clinical effects of arterial hyperoxia or normobaric supplemental oxygen in critical care are listed in Table 1. As highlighted in recent metaanalyses [51, 52], the effects on major clinical endpoints are conflicting and may be partially explained by heterogeneous methodology and subgroup differences in critically ill patients. Pooled effect estimates favoring normoxia are quite consistent, but the harmful effects were previously shown to be impacted by the definition of hyperoxia and may be more pertinent to specific subgroups and at specific moments of admission.

It is well established that the use of higher $\mathrm{FiO}_{2}$ can lead to progressive hypercapnia during a state of chronic compensated respiratory acidosis, and serious adverse outcomes have been shown in acute exacerbations of chronic obstructive pulmonary disease or asthma [53-55]. Likewise, high fractions of oxygen in the inspired air and arterial blood have been associated with increased mortality in mechanically ventilated patients [56].

Owing to a striking lack of robust clinical trials, a causal relationship is still uncertain and both the magnitude and direction of the associations depend on the adjustment for illness severity scores, $\mathrm{FiO}_{2}$, and other confounders [56, 57]. Future randomized controlled studies are urgently needed to definitively elucidate the causal effects of oxygenation targets and derangements on clinical outcomes of critically ill patients.

Excessive oxygenation may be most intensively studied after resuscitation from cardiac arrest as both the vascular alterations and the ischemia and reperfusion injury are hypothesized to be hazardous [58]. In a dose-dependent manner, hyperoxia has been linked to worse outcome in these patients [59-62]. The adverse association was not systematically reproduced and this was possibly due to heterogeneity in study methods [63-68]. The only randomized controlled trial in the post-resuscitation period found that $30 \%$ oxygen ventilation was not worse in comparison with $100 \%$ oxygen, but the study was underpowered to detect significant differences [69]. In view of all recent data, supplemental oxygen administration during resuscitation still appears desirable, but hyperoxia should be avoided in the post-resuscitation phase and saturation should be targeted at 94-96\% $[58,70]$.

A large number of both experimental and clinical studies have primed pediatricians with great awareness of the risks of hyperoxia. For neonatal resuscitation, the routine use of $100 \%$ oxygen has been abandoned after numerous associations with myocardial, neurological, and kidney injury and retinopathy, inflammation, and increased mortality [71, 72]. However, strict adherence to lower target ranges of oxygen saturation among preterm infants did not significantly reduce disability or deaths [73]. Results from a prospective large-scale meta-analysis investigating the most appropriate level of oxygenation for extremely preterm neonates suggested that functional oxyhemoglobin saturation be targeted at 90-95\% in the post-natal period [74].

Hyperoxia-induced vasoconstriction poses a major concern in the management of acute coronary syndromes, and guidelines increasingly suggest a restriction of supplementary oxygen to only those at increased risk for hypoxia [75]. Indeed, oxygen therapy has not been shown to be beneficial after acute myocardial infarction and may even be harmful, causing a marked reduction in coronary blood flow and myocardial oxygen consumption [76, 77]. The vasoconstriction caused by hyperoxia may be of special concern in the acute setting before reperfusion. The AVOID (Air Verses Oxygen In myocarDial infarction) trial aimed to definitively qualify the role of supplemental oxygen in acute myocardial infarction [78] and found increased myocardial injury, recurrent myocardial infarction, cardiac arrhythmia, and infarct size at 6 months [79]. In contrast, a smaller trial observed a beneficial effect of 30-40\% oxygen inhalation over controls during both occlusion and reperfusion [80]. Hemodynamic effects may also be pertinent to acute ischemic stroke patients, who do not appear to benefit from increased survival after prolonged treatment with oxygen $[81,82]$.

Despite the theoretical benefit of decreasing intracranial pressure through cerebral vasoconstriction, hyperoxia has repeatedly been associated with delayed cerebral ischemia and increased cerebral excitotoxicity after cerebrovascular incidents [83-85]. Interestingly, the synergistic combination of hyperbaric and normobaric hyperoxia was recently found to have potential therapeutic efficacy in severe traumatic brain injury [86]. However, observational data in patients with traumatic brain injury, ischemic stroke, subarachnoid, or intracerebral hemorrhage remain equivocal [87-92].

\section{Perioperative care}

Liberal oxygen supply is usually accepted in perioperative care in order to avoid potentially life-threatening consequences of hypoxia during surgery. Further effects 
Table 1 Studies assessing the clinical effects of arterial hyperoxia or supplemental oxygen in subgroups of critically ill patients

\begin{tabular}{|c|c|c|c|c|c|c|c|}
\hline Author & Country & Study type & Inclusion period & Subgroup & Sample size & Harm & Conclusions \\
\hline Eastwood et al. [57] (2012) & $\begin{array}{l}\text { Australia and } \\
\text { New Zealand }\end{array}$ & Cohort & $2000-2009$ & MV & 152,680 & - & $\begin{array}{l}\text { Hypoxia in first } 24 \mathrm{~h} \text { of admission was associated with increased } \\
\text { in-hospital mortality, but hyperoxia was not. }\end{array}$ \\
\hline de Jonge et al. [56] (2008) & The Netherlands & Cohort & 1999-2006 & MV & 36,307 & + & $\begin{array}{l}\text { High } \mathrm{FiO}_{2} \text { and both low } \mathrm{PaO}_{2} \text { and high } \mathrm{PaO}_{2} \text { in first } 24 \mathrm{~h} \text { of } \\
\text { admission were associated with in-hospital mortality }\end{array}$ \\
\hline Suzuki et al. [96] (2014) & Australia & Before-after pilot & 2012 & MV & 105 & $+/-$ & $\begin{array}{l}\text { Conservative oxygen therapy in mechanically ventilated ICU } \\
\text { patients was feasible and free of adverse biochemical, } \\
\text { physiological, or clinical outcomes while allowing a marked } \\
\text { decrease in excess oxygen exposure }\end{array}$ \\
\hline Aboab et al. [41] (2006) & France & Experimental & NA & ARDS & 14 & $+/-$ & $\begin{array}{l}\text { In mechanically ventilated patients with ARDS, the breathing } \\
\text { of pure oxygen leads to alveolar derecruitment, which is } \\
\text { prevented by high PEEP }\end{array}$ \\
\hline Austin et al. [53] (2010) & Australia & RCT & $2006-2007$ & COPD & 405 & + & $\begin{array}{l}\text { Titrated oxygen treatment significantly reduced mortality, } \\
\text { hypercapnia, and respiratory acidosis compared with } \\
\text { high-flow oxygen in acute exacerbations of COPD }\end{array}$ \\
\hline Cameron et al. [55] (2012) & New Zealand & Cohort & $2005-2008$ & COPD & 180 & + & $\begin{array}{l}\text { Serious adverse clinical outcomes are associated with both } \\
\text { hypoxaemia and hyperoxaemia during acute exacerbations }\end{array}$ \\
\hline Perrin et al. [54] (2011) & New Zealand & RCT & $2007-2009$ & Asthma & 106 & + & $\begin{array}{l}\text { High-concentration oxygen therapy causes a clinically } \\
\text { significant increase in transcutaneous } \mathrm{CO}_{2} \text { during } \\
\text { severe exacerbations }\end{array}$ \\
\hline Bellomo et al. [63] (2011) & $\begin{array}{l}\text { Australia and } \\
\text { New Zealand }\end{array}$ & Cohort & 2000-2009 & CA & 12,108 & - & $\begin{array}{l}\text { Hyperoxia did not have a robust or consistently reproducible } \\
\text { association with mortality }\end{array}$ \\
\hline Elmer et al. [62] (2014) & USA & Cohort & 2008-2010 & CA & 184 & + & $\begin{array}{l}\text { Severe hyperoxia was independently associated with } \\
\text { decreased survival to hospital discharge }\end{array}$ \\
\hline Ihle et al. [64] (2013) & Australia & Cohort & $2007-2011$ & CA & 584 & - & $\begin{array}{l}\text { Hyperoxia within the first } 24 \mathrm{~h} \text { was not associated with } \\
\text { increased hospital mortality }\end{array}$ \\
\hline Janz et al. [61] (2012) & USA & Cohort & 2007-2012 & CA & 170 & + & $\begin{array}{l}\text { Higher levels of the maximum measured } \mathrm{PaO}_{2} \text { were } \\
\text { associated with increased in-hospital mortality and } \\
\text { poor neurological status on hospital discharge }\end{array}$ \\
\hline Kilgannon et al. [59] (2010) & USA & Cohort & $2001-2005$ & CA & 6326 & + & $\begin{array}{l}\text { Arterial hyperoxia was independently associated with } \\
\text { increased in-hospital mortality compared with either } \\
\text { hypoxia or normoxia }\end{array}$ \\
\hline Kilgannon et al. [60] (2011) & USA & Cohort substudy & $2001-2005$ & CA & 4459 & + & $\begin{array}{l}\text { Supranormal oxygen tension was dose-dependently } \\
\text { associated with the risk of in-hospital death }\end{array}$ \\
\hline Kuisma et al. [69] (2006) & Finland & RCT pilot & NA & CA & 28 & - & $\begin{array}{l}\text { No indication that } 30 \% \text { oxygen with } \mathrm{SpO}_{2} \text { monitoring } \\
\text { did worse than the group receiving } 100 \% \text { oxygen }\end{array}$ \\
\hline Lee et al. [65] (2014) & Korea & Cohort & 2008-2012 & CA & 213 & - & $\begin{array}{l}\text { Mean } \mathrm{PaO}_{2} \text { was not independently associated with } \\
\text { in-hospital mortality }\end{array}$ \\
\hline Nelskyla et al. [112] (2013) & Australia & Cohort & 2008-2010 & CA & 122 & - & $\begin{array}{l}\text { No statistically significant differences in numbers of } \\
\text { patients discharged from the hospital and } 30 \text {-day survival } \\
\text { between patients with hyperoxia exposure and no exposure }\end{array}$ \\
\hline Spindelboeck et al. [67] (2013) & Austria & Cohort & 2003-2010 & CA & 145 & - & $\begin{array}{l}\text { Increasing } \mathrm{PaO}_{2} \text { was associated with a significantly increased } \\
\text { rate of hospital admission and not with harmful effects }\end{array}$ \\
\hline
\end{tabular}


Table 1 Studies assessing the clinical effects of arterial hyperoxia or supplemental oxygen in subgroups of critically ill patients (Continued)

\begin{tabular}{|c|c|c|c|c|c|c|c|}
\hline Vaahersalo et al. [66] (2014) & Finland & Cohort & 2010-2011 & CA & 409 & - & $\begin{array}{l}\text { Hypercapnia was associated with good 12-month outcome, } \\
\text { but harm from hyperoxia exposure was not verified }\end{array}$ \\
\hline Minana et al. [113] (2011) & Spain & Cohort & 2003-2009 & ADHF & 588 & - & $\begin{array}{l}\text { Admission } \mathrm{PaO}_{2} \text { was not associated with all-cause } \\
\text { long-term mortality }\end{array}$ \\
\hline Ranchord et al. [114] (2012) & New Zealand & RCT pilot & 2007-2009 & STEMI & 136 & - & $\begin{array}{l}\text { No evidence of benefit or harm from high-concentration } \\
\text { compared with titrated oxygen }\end{array}$ \\
\hline Stub et al. [78] (2012) & Australia & $\mathrm{RCT}$ & $2011-2014$ & STEMI & 441 & + & $\begin{array}{l}\text { Supplemental oxygen therapy in patients with STEMI but } \\
\text { without hypoxia increased myocardial injury, recurrent } \\
\text { myocardial infarction, and cardiac arrhythmia and was } \\
\text { associated with larger myocardial infarct size at } 6 \text { months. } \\
\text { Further results anticipated. }\end{array}$ \\
\hline Sutton et al. [115] (2014) & $\begin{array}{l}\text { Australia and } \\
\text { New Zealand }\end{array}$ & Cohort & 2003-2012 & $\begin{array}{l}\text { Post cardiac } \\
\text { surgery }\end{array}$ & 83,060 & - & $\begin{array}{l}\text { No association between mortality and hyperoxia in the } \\
\text { first } 24 \mathrm{~h} \text { in ICU after cardiac surgery }\end{array}$ \\
\hline Ukholkina et al. [80] (2005) & Russia & RCT & NA & $\mathrm{AMI}$ & 137 & - & $\begin{array}{l}\text { Inhalation of } 30-40 \% \text { oxygen within } 30 \text { min prior to } \\
\text { endovascular myocardial reperfusion and within } 4 \mathrm{~h} \\
\text { thereafter reduced the area of necrosis and peri-infarction } \\
\text { area, improved central hemodynamics, and decreased the } \\
\text { rate of post-operative rhythm disorders as compared with } \\
\text { patients breathing ambient air }\end{array}$ \\
\hline Zughaft et al. [116] (2013) & Sweden & RCT & NA & ACS & 300 & - & $\begin{array}{l}\text { The use of oxygen during } \mathrm{PCl} \text { did not demonstrate any } \\
\text { analgesic effect and no difference in myocardial injury } \\
\text { measured with troponin- } t \text { or in the morphine dose }\end{array}$ \\
\hline Asher et al. [89] (2013) & USA & Cohort & NA & $\mathrm{TB} \mid$ & 193 & - & $\begin{array}{l}\mathrm{PaO}_{2} \text { threshold between } 250 \text { and } 486 \mathrm{~mm} \mathrm{Hg} \text { during the } \\
\text { first } 72 \mathrm{~h} \text { after injury was associated with improved all-cause } \\
\text { survival independently of hypocarbia or hypercarbia }\end{array}$ \\
\hline Brenner et al. [88] (2012) & USA & Cohort & $2002-2007$ & TBI & 1547 & + & $\begin{array}{l}\text { Hyperoxia within the first } 24 \mathrm{~h} \text { of hospitalization was } \\
\text { associated with worse short-term functional outcomes } \\
\text { and higher mortality }\end{array}$ \\
\hline Davis et al. [87] (2009) & USA & Cohort & 1987-2003 & TBI & 3420 & + & $\begin{array}{l}\text { Both hypoxemia and extreme hyperoxemia were associated } \\
\text { with increased mortality and a decrease in good outcomes }\end{array}$ \\
\hline Quintard et al. [83] (2014) & Switzerland & Cohort & 2009-2013 & TBI & 36 & + & $\begin{array}{l}\text { Incremental normobaric } \mathrm{FiO}_{2} \text { levels were associated with } \\
\text { increased cerebral excitotoxicity independently from brain } \\
\text { tissue oxygen and other important cerebral and } \\
\text { systemic determinants }\end{array}$ \\
\hline Raj et al. [90] (2013) & Finland & Cohort & 2003-2012 & $\mathrm{TB} \mid$ & 1116 & - & $\begin{array}{l}\text { Hyperoxemia in the first } 24 \mathrm{~h} \text { of admission was not predictive } \\
\text { of } 6 \text {-month mortality }\end{array}$ \\
\hline Rincon et al. [92] (2013) & USA & Cohort & 2003-2008 & $\mathrm{TB} \mid$ & 1212 & + & $\begin{array}{l}\text { Arterial hyperoxia was independently associated with higher } \\
\text { in-hospital case fatality }\end{array}$ \\
\hline Jeon et al. [84] (2014) & USA & Cohort & 1996-2011 & Stroke & 252 & + & $\begin{array}{l}\text { Exposure to hyperoxia was associated with delayed } \\
\text { cerebral ischemia }\end{array}$ \\
\hline Rincon et al. [85] (2014) & USA & Cohort & 2003-2008 & Stroke & 2894 & + & $\begin{array}{l}\text { Arterial hyperoxia was independently associated with } \\
\text { in-hospital death as compared with either normoxia } \\
\text { or hypoxia }\end{array}$ \\
\hline
\end{tabular}


Table 1 Studies assessing the clinical effects of arterial hyperoxia or supplemental oxygen in subgroups of critically ill patients (Continued)

\begin{tabular}{|c|c|c|c|c|c|c|c|}
\hline $\begin{array}{l}\text { Ali et al. [82] (2014) and } \\
\text { Roffe et al. [117] (2011) }\end{array}$ & UK & RCT pilot & $2004-2008$ & Stroke & 289 & - & $\begin{array}{l}\text { Routine oxygen supplementation started within } 24 \text { h of } \\
\text { hospital admission with acute stroke led to a small } \\
\text { improvement in neurological recovery at } 1 \text { week, but no } \\
\text { outcome differences were observed at } 6 \text { months }\end{array}$ \\
\hline Ronning et al. [81] (1999) & Norway & Quasi-RCT & 1994-1995 & Stroke & 310 & + & $\begin{array}{l}\text { Supplemental oxygen should not routinely be given to } \\
\text { non-hypoxic patients with minor or moderate strokes }\end{array}$ \\
\hline Singhal et al. [118] (2005) & USA & RCT pilot & NA & Stroke & 16 & - & $\begin{array}{l}\text { High-flow oxygen therapy is associated with a transient } \\
\text { improvement of clinical deficits and MRl abnormalities }\end{array}$ \\
\hline Young et al. [91] (2012) & $\begin{array}{l}\text { Australia and } \\
\text { New Zealand }\end{array}$ & Cohort & 2000-2009 & Stroke & 2643 & - & $\begin{array}{l}\text { Worst arterial oxygen tension in the first } 24 \mathrm{~h} \text { was not } \\
\text { associated with outcome }\end{array}$ \\
\hline Stolmeijer et al. [119] (2014) & The Netherlands & Cohort & NA & Sepsis & 83 & - & $\begin{array}{l}\text { No association between mortality and hyperoxia, nor } \\
\text { between lower } \mathrm{FiO}_{2} \text { and other detrimental effects }\end{array}$ \\
\hline
\end{tabular}

NA, not available; +, study found harm from supplemental oxygen or arterial hyperoxia; -, no harm found from supplemental oxygen or arterial hyperoxia

ACS Acute coronary syndrome, ADHF Acute decompensated heart failure, AMI Acute myocardial infarction, ARDS Acute respiratory distress syndrome, $C A$ Cardiac arrest, $C \mathrm{O}_{2}$ Carbon dioxide, COPD Chronic obstructive pulmonary disease, $\mathrm{FiO}_{2}$ Fraction of inspired oxygen, ICU Intensive care unit, $M R I$ Magnetic resonance imaging, $\mathrm{PaO}_{2}$ Partial pressure of arterial oxygen, $P C l$ Percutaneous coronary intervention, $M V$ Mechanical ventilation, PEEP Positive end-expiratory pressure, $R C T$ Randomized control trial, $\mathrm{SpO}_{2}$ Oxyhemoglobin saturation, STEMI ST-segment elevation myocardial infarction, TBI Traumatic brain injury 
of perioperative hyperoxia have been comprehensively summarized in meta-analyses enrolling over 7000 patients and generally showed a reduced risk of surgical site infections and postoperative nausea without luxation of postoperative atelectasis [93, 94]. However, risks may outweigh benefits in specific age groups [39] and different subsets. This was recently highlighted in patients undergoing cancer surgery in whom $80 \%$ oxygen supply in the perioperative setting showed a significantly increased long-term all-cause mortality compared with those randomly assigned to $30 \%$ [95].

\section{Implications for therapy}

Several therapeutic options that limit the harmful effects of hyperoxia can be contemplated, but prevention of excessive oxygenation is likely to be the most effective strategy. A rational approach may be a more conservative administration strategy in which oxygen is titrated to a lower tolerable level in order to prevent iatrogenic harm while preserving adequate tissue oxygenation. Recently, a pilot interventional study showed that conservative oxygen therapy in mechanically ventilated patients in the ICU can be feasible and free of adverse outcomes while decreasing excess oxygen exposure [96]. Importantly, when the risks for severe tissue hypoxia are pronounced, ample oxygen supply remains vital and should be started immediately to increase oxygen delivery and preserve tissue oxygenation. Also, oxygen may aid hemodynamic stabilization and decrease intracranial pressure and can be used to stimulate erythropoietin and increase hemoglobin when intermittent hyperoxia is used as a paradoxical trigger for HIF expression.

Experimental interventions to decrease harm from hyperoxia are targeted at numerous steps in the pathway of ROS-induced damage. The primary source for intervention in the oxidative cycle is inhibition of oxidant generation, either quantitatively or qualitatively. Bleomycin and amiodarone are well-known originators of drug-induced pulmonary disease and should be avoided to minimize preventable ROS formation [97, 98]. Limiting the exposure to other exogenous stimuli or preventing electron leakage in the electron transport chain may protect the mitochondria, but this strategy proves cumbersome in actual practice. Although the clinical applicability has been questioned because of little or no preventative or therapeutic effect, the supply of antioxidant enzymes may be a feasible approach to facilitate the conversion, avoid the intermediate formation, and reduce the concentration of strongly reactive oxidants. However, some of these antioxidants may actually have pro-oxidant properties, depending on their concentration and interaction with other molecules. The neutralizing effect of antioxidants may not be sufficient to secure metabolic stability, even when secondary inflammation is mitigated.
Finally, oxidant scavenging can shift the balance toward harm when the role of oxidants in cell signaling pathways is suppressed [99].

As an alternative, pathways of cell integrity, cell death, and inflammation may be targeted to reduce further damage and enhance the defense against oxygen radicals. Experimental research suggests protective effects through modulation of protein kinases $[100,101]$ and transcription factors [102-105]. Moreover, numerous preclinical studies have demonstrated that manipulation of chemokines, cytokines [13, 106], growth factors [107], receptors [108-110], and DAMPs $[11,12,111]$ may limit hyperoxia-induced injury, but these targets all remain to be evaluated at the bedside.

\section{Conclusions}

Although oxygen remains of life-saving importance in critical care, accumulating evidence has demonstrated the prominent role of hyperoxia and the consequent formation of ROS in the pathogenesis of several lifethreatening diseases. The toxic effects of supraphysiological oxygen concentrations are driven by cell damage, cell death, and inflammation. These aspects are of special concern in the pulmonary compartment, where absorptive atelectasis impairs respiratory function at high inspiratory oxygen levels. The cerebral and coronary circulations are at specific risk when vascular alterations manifest. Long-term exposure to hyperoxia impairs the innate immune response and increases susceptibility to infectious complications and tissue injury. Given that critically ill patients are prone to inflammation, cardiovascular instability, and depleted antioxidant mechanisms, the most rational practice may be to supply oxygen conservatively and titrate the therapy carefully to the patient's needs. However, our understanding of oxygen toxicity is limited in humans, and conflicting findings hamper the constitution of compelling guidelines. Further research is warranted to study hyperoxia-induced effects in clinical practice, to elucidate time-and dose-response relationships, and to provide evidence-based oxygenation targets and interventions through robust clinical trials.

\section{Abbreviations}

DAMP: Damage-associated molecular pattern molecule; $\mathrm{FiO}_{2}$ : Fraction of inspired oxygen; HIF: Hypoxia-inducible factor; ICU: Intensive care unit; $\mathrm{PaO}_{2}$ : Partial pressure of arterial oxygen; PMN: Polymorphonuclear neutrophil; ROS: Reactive oxygen species.

\section{Competing interests}

The authors declare that they have no competing interests.

\section{Authors' contributions}

HJFH participated in study conception and drafted the manuscript. MJS and PHJvdV participated in the interpretation and critical revision of the article for important intellectual content. EdJ and DJvW participated in study design, interpretation, and critical revision. All authors read and approved the final manuscript. 


\section{Acknowledgments}

For the preparation of Fig. 1, the creative support of Iris Levert is gratefully acknowledged.

\section{Author details}

'Department of Intensive Care Medicine, Leiden University Medical Center, Albinusdreef 2, Leiden 2300 RC, The Netherlands. ${ }^{2}$ Laboratory of Experimental Intensive Care and Anesthesiology, Academic Medical Center, Meibergdreef 9, Amsterdam 1105 AZ, The Netherlands. ${ }^{3}$ Department of Intensive Care Medicine, Academic Medical Center, Meibergdreef 9, Amsterdam 1105 AZ, The Netherlands. ${ }^{4}$ Department of Intensive Care Medicine, Onze Lieve Vrouwe Gasthuis, Oosterpark 9, Amsterdam 1091 AZ, The Netherlands. ${ }^{5}$ TIAS School for Business and Society, Tilburg University, Warandelaan 2, Tilburg 5000 LE, The Netherlands.

\section{Published online: 17 August 2015}

\section{References}

1. Bitterman H. Bench-to-bedside review: oxygen as a drug. Crit Care. 2009;13:205.

2. Vincent JL, De Backer D. Circulatory shock. N Engl J Med. 2013;369:1726-34.

3. Altemeier WA, Sinclair SE. Hyperoxia in the intensive care unit: why more is not always better. Curr Opin Crit Care. 2007;13:73-8.

4. Magder S. Reactive oxygen species: toxic molecules or spark of life? Crit Care. 2006;10:208.

5. Ray PD, Huang BW, Tsuji Y. Reactive oxygen species (ROS) homeostasis and redox regulation in cellular signaling. Cell Signal. 2012;24:981-90.

6. Turrens JF. Mitochondrial formation of reactive oxygen species. J Physiol. 2003;552:335-44

7. Comhair SA, Erzurum SC. Antioxidant responses to oxidant-mediated lung diseases. Am J Physiol Lung Cell Mol Physiol. 2002;283:L246-55.

8. Nathan C, Cunningham-Bussel A. Beyond oxidative stress: an immunologist's guide to reactive oxygen species. Nat Rev Immunol. 2013;13:349-61.

9. Barazzone C, Horowitz S, Donati YR, Rodriguez I, Piguet PF. Oxygen toxicity in mouse lung: pathways to cell death. Am J Respir Cell Mol Biol. 1998;19:573-81.

10. Zhang Q, Raoof M, Chen Y, Sumi Y, Sursal T, Junger W, et al. Circulating mitochondrial DAMPs cause inflammatory responses to injury. Nature. 2010;464:104-7.

11. Kuipers MT, van der Poll T, Schultz MJ, Wieland CW. Bench-to-bedside review: damage-associated molecular patterns in the onset of ventilatorinduced lung injury. Crit Care. 2011;15:235.

12. Chan JK, Roth J, Oppenheim JJ, Tracey KJ, Vogl T, Feldmann M, et al. Alarmins: awaiting a clinical response. J Clin Invest. 2012;122:2711-9.

13. Bhandari $V$, Elias JA. Cytokines in tolerance to hyperoxia-induced injury in the developing and adult lung. Free Radic Biol Med. 2006;41:4-18.

14. Baleeiro CE, Wilcoxen SE, Morris SB, Standiford TJ, Paine 3rd R. Sublethal hyperoxia impairs pulmonary innate immunity. J Immunol. 2003;171:955-63.

15. Krysko DV, Agostinis P, Krysko O, Garg AD, Bachert C, Lambrecht BN, et al. Emerging role of damage-associated molecular patterns derived from mitochondria in inflammation. Trends Immunol. 2011;32:157-64.

16. Eltzschig HK, Carmeliet P. Hypoxia and inflammation. N Engl J Med. 2011;364:656-65

17. Rocco M, D'Itri L, De Bels D, Corazza F, Balestra C. The "normobaric oxygen paradox": a new tool for the anesthetist? Minerva Anestesiol. 2014;80:366-72.

18. Crapo JD. Morphological-changes in pulmonary oxygen-toxicity. Annu Rev Plant Physiol Plant Mol Biol. 1986;48:721-31.

19. Lodato RF. Effects of normobaric hyperoxia on hemodynamics and $\mathrm{O} 2$ utilization in conscious dogs. Adv Exp Med Biol. 1990;277:807-15.

20. Lodato RF. Decreased $\mathrm{O} 2$ consumption and cardiac output during normobaric hyperoxia in conscious dogs. J Appl Physiol (1985). 1989;67:1551-9.

21. Fracica PJ, Knapp MJ, Piantadosi CA, Takeda K, Fulkerson WJ, Coleman RE, et al. Responses of baboons to prolonged hyperoxia: physiology and qualitative pathology. J Appl Physiol (1985). 1991;71:2352-62.

22. Bailey TC, Martin EL, Zhao L, Veldhuizen RA. High oxygen concentrations predispose mouse lungs to the deleterious effects of high stretch ventilation. J Appl Physiol (1985). 2003;94:975-82

23. Nagato AC, Bezerra FS, Lanzetti M, Lopes AA, Silva MA, Porto LC, et al. Time course of inflammation, oxidative stress and tissue damage induced by hyperoxia in mouse lungs. Int J Exp Pathol. 2012;93:269-78.
24. Nagato A, Silva FL, Silva AR, Bezerra FS, Oliveira ML, Bello-Klein A, et al. Hyperoxia-induced lung injury is dose dependent in Wistar rats. Exp Lung Res. 2009;35:713-28.

25. Hou L, Xie K, Qin M, Peng D, Ma S, Shang L, et al. Effects of reactive oxygen species scavenger on the protective action of $100 \%$ oxygen treatment against sterile inflammation in mice. Shock. 2010;33:646-54.

26. Waisman D, Brod V, Rahat MA, Amit-Cohen BC, Lahat N, Rimar D, et al. Dose-related effects of hyperoxia on the lung inflammatory response in septic rats. Shock. 2012;37:95-102.

27. Kikuchi Y, Tateda K, Fuse ET, Matsumoto T, Gotoh N, Fukushima J, et al. Hyperoxia exaggerates bacterial dissemination and lethality in Pseudomonas aeruginosa pneumonia. Pulm Pharmacol Ther. 2009;22:333-9.

28. Rodriguez-Gonzalez R, Martin-Barrasa JL, Ramos-Nuez A, Canas-Pedrosa AM, Martinez-Saavedra MT, Garcia-Bello MA, et al. Multiple system organ response induced by hyperoxia in a clinically relevant animal model of sepsis. Shock. 2014;42:148-53.

29. Tateda K, Deng JC, Moore TA, Newstead MW, Paine 3rd R, Kobayashi N, et al. Hyperoxia mediates acute lung injury and increased lethality in murine Legionella pneumonia: the role of apoptosis. J Immunol. 2003;170:4209-16.

30. Barth E, Bassi G, Maybauer DM, Simon F, Groger M, Oter S, et al. Effects of ventilation with $100 \%$ oxygen during early hyperdynamic porcine fecal peritonitis. Crit Care Med. 2008;36:495-503.

31. Sukhotnik I, Krausz MM, Brod V, Balan M, Turkieh A, Siplovich L, et al. Divergent effects of oxygen therapy in four models of uncontrolled hemorrhagic shock. Shock. 2002;18:277-84.

32. Li LF, Liao SK, Ko YS, Lee CH, Quinn DA. Hyperoxia increases ventilatorinduced lung injury via mitogen-activated protein kinases: a prospective, controlled animal experiment. Crit Care. 2007;11:R25.

33. Makena PS, Luellen CL, Balazs L, Ghosh MC, Parthasarathi K, Waters CM, et al. Preexposure to hyperoxia causes increased lung injury and epithelial apoptosis in mice ventilated with high tidal volumes. Am J Physiol Lung Cell Mol Physiol. 2010;299:L711-9.

34. Quinn DA, Moufarrej RK, Volokhov A, Hales CA. Interactions of lung stretch hyperoxia, and MIP-2 production in ventilator-induced lung injury. J Appl Physiol (1985). 2002;93:517-25.

35. Liu YY, Liao SK, Huang CC, Tsai YH, Quinn DA, Li LF. Role for nuclear factorkappaB in augmented lung injury because of interaction between hyperoxia and high stretch ventilation. Transl Res. 2009;154:228-40.

36. Cannizzaro V, Berry LJ, Zosky GR, Turner DJ, Hantos Z, Sly PD. Impact of supplemental oxygen in mechanically ventilated adult and infant mice. Respir Physiol Neurobiol. 2009;165:61-6.

37. Andrade PV, Dos Santos JM, Silva HC, Wilbert DD, Cavassani SS, OliveiraJunior IS. Influence of hyperoxia and mechanical ventilation in lung inflammation and diaphragm function in aged versus adult rats. Inflammation. 2014;37:486-94.

38. Cavassani SS, Junqueira VB, Moraes JB, Luzo KK, Silva CM, Barros M, et al. Short courses of mechanical ventilation with high-O2 levels in elderly rat lungs. Acta Cir Bras. 2011;26:107-13.

39. Habre W, Petak F. Perioperative use of oxygen: variabilities across age. Br J Anaesth. 2014;113:26-36.

40. Asfar $P$, Singer $M$, Radermacher $P$. Understanding the benefits and harms of oxygen therapy. Intensive Care Med. 2015 Jan 30. [Epub ahead of print].

41. Aboab J, Jonson B, Kouatchet A, Taille S, Niklason L, Brochard L. Effect of inspired oxygen fraction on alveolar derecruitment in acute respiratory distress syndrome. Intensive Care Med. 2006;32:1979-86.

42. Capellier G, Panwar R. Is it time for permissive hypoxaemia in the intensive care unit? Crit Care Resusc. 2011;13:139-41.

43. Kapanci Y, Tosco R, Eggermann J, Gould VE. Oxygen pneumonitis in man. Light- and electron-microscopic morphometric studies. Chest. 1972;62:162-9.

44. Smith JL. The pathological effects due to increase of oxygen tension in the air breathed. J Physiol. 1899;24:19-35.

45. Bak Z, Sjoberg F, Rousseau A, Steinvall I, Janerot-Sjoberg B. Human cardiovascular dose-response to supplemental oxygen. Acta Physiol (Oxf). 2007;191:15-24.

46. Floyd TF, Clark JM, Gelfand R, Detre JA, Ratcliffe S, Guvakov D, et al. Independent cerebral vasoconstrictive effects of hyperoxia and accompanying arterial hypocapnia at 1 ATA. J Appl Physiol (1985). 2003;95:2453-61.

47. Iscoe S, Beasley R, Fisher JA. Supplementary oxygen for nonhypoxemic patients: O2 much of a good thing? Crit Care. 2011;15:305.

48. Waring WS, Thomson AJ, Adwani SH, Rosseel AJ, Potter JF, Webb DJ, et al Cardiovascular effects of acute oxygen administration in healthy adults. J Cardiovasc Pharmacol. 2003;42:245-50. 
49. Calzia E, Asfar P, Hauser B, Matejovic M, Ballestra C, Radermacher P, et al. Hyperoxia may be beneficial. Crit Care Med. 2010;38:S559-68.

50. Kemming Gl, Meisner FG, Kleen M, Meier JM, Tillmanns J, Hutter JW, et al. Hyperoxic ventilation at the critical haematocrit. Resuscitation. 2003;56:289-97.

51. Helmerhorst HJF, Roos-Blom M-J, van Westerloo DJ, de Jonge E. Association between arterial hyperoxia and outcome in subsets of critical illness: a systematic review, meta-analysis, and meta-regression of cohort studies. Crit Care Med. 2015;43:1508-19.

52. Damiani E, Adrario E, Girardis M, Romano R, Pelaia P, Singer M, et al. Arterial hyperoxia and mortality in critically ill patients: a systematic review and meta-analysis. Crit Care. 2014;18:711.

53. Austin MA, Wills KE, Blizzard L, Walters EH, Wood-Baker R. Effect of high flow oxygen on mortality in chronic obstructive pulmonary disease patients in prehospital setting: randomised controlled trial. BMJ. 2010;341:C5462.

54. Perrin K, Wijesinghe M, Healy B, Wadsworth K, Bowditch R, Bibby S, et al. Randomised controlled trial of high concentration versus titrated oxygen therapy in severe exacerbations of asthma. Thorax. 2011;66:937-41.

55. Cameron L, Pilcher J, Weatherall M, Beasley R, Perrin K. The risk of serious adverse outcomes associated with hypoxaemia and hyperoxaemia in acute exacerbations of COPD. Postgrad Med J. 2012;88:684-9.

56. de Jonge $E$, Peelen $L$, Keijzers PJ, Joore $H$, de Lange $D$, van der Voort $P H$, et al. Association between administered oxygen, arterial partial oxygen pressure and mortality in mechanically ventilated intensive care unit patients. Crit Care. 2008;12:R156.

57. Eastwood G, Bellomo R, Bailey M, Taori G, Pilcher D, Young P, et al. Arterial oxygen tension and mortality in mechanically ventilated patients. Intensive Care Med. 2012;38:91-8.

58. Dell'Anna A, Lamanna I, Vincent $J$, Taccone F. How much oxygen in adult cardiac arrest? Crit Care. 2014;18:555.

59. Kilgannon JH, Jones $\mathrm{AE}$, Shapiro $\mathrm{NI}$, Angelos MG, Milcarek $\mathrm{B}$, Hunter $\mathrm{K}$, et al. Association between arterial hyperoxia following resuscitation from cardiac arrest and in-hospital mortality. JAMA. 2010;303:2165-71.

60. Kilgannon JH, Jones AE, Parrillo JE, Dellinger RP, Milcarek B, Hunter K, et al. Relationship between supranormal oxygen tension and outcome after resuscitation from cardiac arrest. Circulation. 2011;123:2717-22.

61. Janz DR, Hollenbeck RD, Pollock JS, McPherson JA, Rice TW. Hyperoxia is associated with increased mortality in patients treated with mild therapeutic hypothermia after sudden cardiac arrest. Crit Care Med. 2012;40:3135-9.

62. Elmer J, Scutella M, Pullalarevu R, Wang B, Vaghasia N, Trzeciak S, et al. The association between hyperoxia and patient outcomes after cardiac arrest: analysis of a high-resolution database. Intensive Care Med. 2015;41:49-57.

63. Bellomo R, Bailey M, Eastwood GM, Nichol A, Pilcher D, Hart GK, et al. Arterial hyperoxia and in-hospital mortality after resuscitation from cardiac arrest. Crit Care. 2011;15:R90.

64. Ihle JF, Bernard S, Bailey MJ, Pilcher DV, Smith K, Scheinkestel CD. Hyperoxia in the intensive care unit and outcome after out-of-hospital ventricular fibrillation cardiac arrest. Crit Care Resusc. 2013;15:186-90.

65. Lee BK, Jeung KW, Lee HY, Lee SJ, Jung YH, Lee WK, et al. Association between mean arterial blood gas tension and outcome in cardiac arrest patients treated with therapeutic hypothermia. Am J Emerg Med. 2014;32:55-60

66. Vaahersalo J, Bendel S, Reinikainen M, Kurola J, Tiainen M, Raj R, et al. Arterial blood gas tensions after resuscitation from out-of-hospital cardiac arrest: associations with long-term neurologic outcome. Crit Care Med. 2014:42:1463-70.

67. Spindelboeck W, Schindler O, Moser A, Hausler F, Wallner S, Strasser C, et al. Increasing arterial oxygen partial pressure during cardiopulmonary resuscitation is associated with improved rates of hospital admission. Resuscitation. 2013:84:770-5.

68. Wang $\mathrm{CH}$, Chang WT, Huang $\mathrm{CH}$, Tsai MS, Yu PH, Wang AY, et al. The effect of hyperoxia on survival following adult cardiac arrest: a systematic review and meta-analysis of observational studies. Resuscitation. 2014;85:1142-8.

69. Kuisma M, Boyd J, Voipio V, Alaspaa A, Roine RO, Rosenberg P. Comparison of 30 and the $100 \%$ inspired oxygen concentrations during early postresuscitation period: a randomised controlled pilot study. Resuscitation. 2006:69:199-206.

70. Eastwood GM, Young PJ, Bellomo R. The impact of oxygen and carbon dioxide management on outcome after cardiac arrest. Curr Opin Crit Care. 2014:20:266-72

71. Tan A, Schulze A, O'Donnell CP, Davis PG. Air versus oxygen for resuscitation of infants at birth. Cochrane Database Syst Rev. 2005;2:CD002273.
72. Saugstad OD, Ramji S, Vento M. Oxygen for newborn resuscitation: how much is enough? Pediatrics. 2006;118:789-92.

73. Schmidt B, Whyte RK, Asztalos EV, Moddemann D, Poets C, Rabi Y, et al. Effects of targeting higher vs lower arterial oxygen saturations on death or disability in extremely preterm infants: a randomized clinical trial. JAMA. 2013;309:2111-20

74. Saugstad OD, Aune D. Optimal oxygenation of extremely low birth weight infants: a meta-analysis and systematic review of the oxygen saturation target studies. Neonatology. 2014;105:55-63.

75. Shuvy M, Atar D, Gabriel Steg P, Halvorsen S, Jolly S, Yusuf S, et al. Oxygen therapy in acute coronary syndrome: are the benefits worth the risk? Eur Heart J. 2013;34:1630-5.

76. Farquhar $\mathrm{H}$, Weatherall M, Wijesinghe M, Perrin K, Ranchord A, Simmonds $M$, et al. Systematic review of studies of the effect of hyperoxia on coronary blood flow. Am Heart J. 2009;158:371-7.

77. Wijesinghe M, Perrin K, Ranchord A, Simmonds M, Weatherall M, Beasley R. Routine use of oxygen in the treatment of myocardial infarction: systematic review. Heart. 2009;95:198-202.

78. Stub D, Smith K, Bernard S, Bray JE, Stephenson M, Cameron P, et al. A randomized controlled trial of oxygen therapy in acute myocardial infarction Air Verses Oxygen In myocarDial infarction study (AVOID Study). Am Heart J. 2012;163:339-45.

79. AVOID Study: Air Versus Oxygen In ST-elevation MyocarDial Infarction. http://my.americanheart.org/idc/groups/ahamah-public/@wcm/@sop/ @scon/documents/downloadable/ucm_469664.pdf. Accessed 01 Jun 2015.

80. Ukholkina GB, Kostyanov IY, Kuchkina NV, Grendo EP, Gofman YB. Effect of oxygenotherapy used in combination with reperfusion in patients with acute myocardial infarction. Kardiologiya. 2005;45:59.

81. Ronning OM, Guldvog B. Should stroke victims routinely receive supplemental oxygen? A quasi-randomized controlled trial. Stroke. 1999;30:2033-7.

82. Ali K, Warusevitane A, Lally F, Sim J, Sills S, Pountain S, et al. The stroke oxygen pilot study: a randomized controlled trial of the effects of routine oxygen supplementation early after acute stroke - effect on key outcomes at six months. PLoS One. 2014;8:e59274.

83. Quintard H, Patet C, Suys T, Marques-Vidal P, Oddo M. Normobaric hyperoxia is associated with increased cerebral excitotoxicity after severe traumatic brain injury. Neurocrit Care. 2015;22:243-50.

84. Jeon SB, Choi HA, Badjatia N, Schmidt JM, Lantigua H, Claassen J, et al. Hyperoxia may be related to delayed cerebral ischemia and poor outcome after subarachnoid haemorrhage. J Neurol Neurosurg Psychiatry. 2014:85:1301-7.

85. Rincon F, Kang J, Maltenfort M, Vibbert M, Urtecho J, Athar MK, et al. Association between hyperoxia and mortality after stroke: a multicenter cohort study. Crit Care Med. 2014;42:387-96.

86. Rockswold SB, Rockswold GL, Zaun DA, Liu J. A prospective, randomized Phase II clinical trial to evaluate the effect of combined hyperbaric and normobaric hyperoxia on cerebral metabolism, intracranial pressure, oxygen toxicity, and clinical outcome in severe traumatic brain injury. J Neurosurg. 2013;118:1317-28.

87. Davis DP, Meade W, Sise MJ, Kennedy F, Simon F, Tominaga G, et al. Both hypoxemia and extreme hyperoxemia may be detrimental in patients with severe traumatic brain injury. J Neurotrauma. 2009;26:2217-23.

88. Brenner M, Stein D, Hu P, Kufera J, Wooford M, Scalea T. Association between early hyperoxia and worse outcomes after traumatic brain injury. Arch Surg. 2012;147:1042-6.

89. Asher SR, Curry P, Sharma D, Wang J, O'Keefe GE, Daniel-Johnson J, et al. Survival advantage and $\mathrm{PaO} 2$ threshold in severe traumatic brain injury. J Neurosurg Anesthesiol. 2013;25:168-73.

90. Raj R, Bendel S, Reinikainen M, Kivisaari R, Siironen J, Lang M, et al. Hyperoxemia and long-term outcome after traumatic brain injury. Crit Care. 2013;17:R177.

91. Young P, Beasley R, Bailey M, Bellomo R, Eastwood GM, Nichol A, et al. The association between early arterial oxygenation and mortality in ventilated patients with acute ischaemic stroke. Crit Care Resusc. 2012;14:14-9.

92. Rincon F, Kang J, Vibbert M, Urtecho J, Athar MK, Jallo J. Significance of arterial hyperoxia and relationship with case fatality in traumatic brain injury: a multicentre cohort study. J Neurol Neurosurg Psychiatry. 2014:85:799-805.

93. Hovaguimian F, Lysakowski C, Elia N, Tramer MR. Effect of intraoperative high inspired oxygen fraction on surgical site infection, postoperative 
nausea and vomiting, and pulmonary function: systematic review and metaanalysis of randomized controlled trials. Anesthesiology. 2013;1 19:303-16.

94. Togioka B, Galvagno S, Sumida S, Murphy J, Ouanes JP, Wu C. The role of perioperative high inspired oxygen therapy in reducing surgical site infection: a meta-analysis. Anesth Analg. 2012;114:334-42.

95. Meyhoff CS, Jorgensen LN, Wetterslev J, Christensen KB, Rasmussen LS, Group PT. Increased long-term mortality after a high perioperative inspiratory oxygen fraction during abdominal surgery: follow-up of a randomized clinical trial. Anesth Analg. 2012;115:849-54.

96. Suzuki S, Eastwood GM, Glassford NJ, Peck L, Young H, Garcia-Alvarez M, et al. Conservative oxygen therapy in mechanically ventilated patients: a pilot before-and-after trial. Crit Care Med. 2014;42:1414-22.

97. Cooper Jr JA, Zitnik RJ, Matthay RA. Mechanisms of drug-induced pulmonary disease. Annu Rev Med. 1988;39:395-404.

98. Kallet RH, Matthay MA. Hyperoxic acute lung injury. Respir Care. 2013;58:123-41.

99. Halliwell B. The antioxidant paradox. Lancet. 2000;355:1179-80.

100. Zhang X, Shan P, Sasidhar M, Chupp GL, Flavell RA, Choi AM, et al. Reactive oxygen species and extracellular signal-regulated kinase 1/2 mitogenactivated protein kinase mediate hyperoxia-induced cell death in lung epithelium. Am J Respir Cell Mol Biol. 2003;28:305-15.

101. Ahmad A, Ahmad S, Chang LY, Schaack J, White CW. Endothelial Akt activation by hyperoxia: role in cell survival. Free Radic Biol Med. 2006;40:1108-18

102. Cho HY, Jedlicka AE, Reddy SP, Kensler TW, Yamamoto M, Zhang LY, et al. Role of NRF2 in protection against hyperoxic lung injury in mice. Am J Respir Cell Mol Biol. 2002;26:175-82.

103. Franek WR, Morrow DM, Zhu H, Vancurova I, Miskolci V, Darley-Usmar K, et al. NF-kappaB protects lung epithelium against hyperoxia-induced nonapoptotic cell death-oncosis. Free Radic Biol Med. 2004:37:1670-9.

104. Lian X, Qin Y, Hossain SA, Yang L, White A, Xu H, et al. Overexpression of Stat3C in pulmonary epithelium protects against hyperoxic lung injury. J Immunol. 2005;174:7250-6.

105. Cramer T, Yamanishi Y, Clausen BE, Forster I, Pawlinski R, Mackman N, et al. HIF-1alpha is essential for myeloid cell-mediated inflammation. Cell. 2003;112:645-57.

106. Ward NS, Waxman AB, Homer RJ, Mantell LL, Einarsson O, Du Y, et al. Interleukin-6-induced protection in hyperoxic acute lung injury. Am J Respir Cell Mol Biol. 2000;22:535-42.

107. Thebaud B, Ladha F, Michelakis ED, Sawicka M, Thurston G, Eaton F, et al. Vascular endothelial growth factor gene therapy increases survival, promotes lung angiogenesis, and prevents alveolar damage in hyperoxia-induced lung injury: evidence that angiogenesis participates in alveolarization. Circulation. 2005;112:2477-86.

108. Sue RD, Belperio JA, Burdick MD, Murray LA, Xue YY, Dy MC, et al. CXCR2 is critical to hyperoxia-induced lung injury. J Immunol. 2004;172:3860-8.

109. Reynolds PR, Schmitt RE, Kasteler SD, Sturrock A, Sanders K, Bierhaus A, et al. Receptors for advanced glycation end-products targeting protect against hyperoxia-induced lung injury in mice. Am J Respir Cell Mol Biol. 2010;42:545-51.

110. Gore A, Muralidhar M, Espey MG, Degenhardt K, Mantell LL. Hyperoxia sensing: from molecular mechanisms to significance in disease. J Immunotoxicol. 2010;7:239-54.

111. Patel VS, Sitapara RA, Gore A, Phan B, Sharma L, Sampat V, et al. High Mobility Group Box-1 mediates hyperoxia-induced impairment of Pseudomonas aeruginosa clearance and inflammatory lung injury in mice. Am J Respir Cell Mol Biol. 2013;48:280-7.

112. Nelskyla A, Parr MJ, Skrifvars MB. Prevalence and factors correlating with hyperoxia exposure following cardiac arrest - an observational single centre study. Scand J Trauma Resusc Emerg Med. 2013;21:35.

113. Minana G, Nunez J, Banuls P, Sanchis J, Nunez E, Robles R, et al. Prognostic implications of arterial blood gases in acute decompensated heart failure. Eur J Intern Med. 2011;22:489-94.

114. Ranchord AM, Argyle R, Beynon R, Perrin K, Sharma V, Weatherall M, et al. High-concentration versus titrated oxygen therapy in ST-elevation myocardial infarction: a pilot randomized controlled trial. Am Heart J. 2012;163:168-75.

115. Sutton AD, Bailey M, Bellomo R, Eastwood GM, Pilcher DV. The association between early arterial oxygenation in the ICU and mortality following cardiac surgery. Anaesth Intensive Care. 2014;42:730-5.

116. Zughaft D, Bhiladvala P, Van Dijkman A, Harnek J, Madsen Hardig B, Bjork J, et al. The analgesic effect of oxygen during percutaneous coronary intervention (the OXYPAIN Trial). Acute Card Care. 2013;15:63-8.
117. Roffe C, Ali K, Warusevitane A, Sills S, Pountain S, Allen M, et al. The SOS pilot study: a RCT of routine oxygen supplementation early after acute stroke - effect on recovery of neurological function at one week. PLOS One. 2011;6:e19113.

118. Singhal AB, Benner T, Roccatagliata L, Koroshetz WJ, Schaefer PW, Lo EH, et al. A pilot study of normobaric oxygen therapy in acute ischemic stroke. Stroke. 2005;36:797-802.

119. Stolmeijer R, ter Maaten JC, Zijlstra JG, Ligtenberg JJ. Oxygen therapy for sepsis patients in the emergency department: a little less? Eur J Emerg Med. 2014:21:233-5 